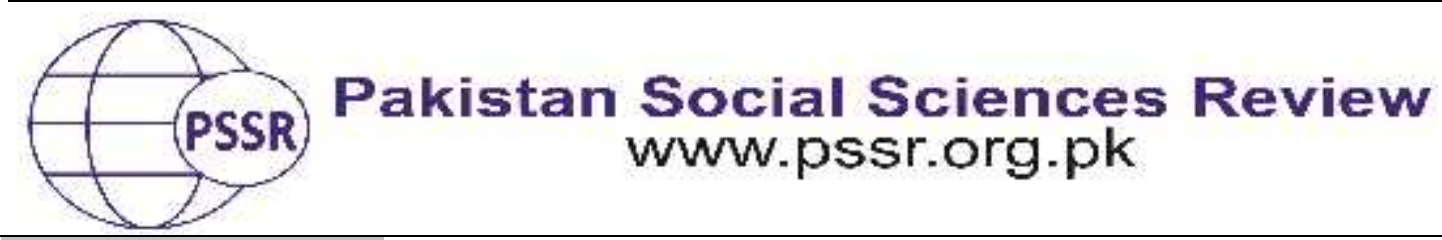

RESEARCH PAPER

\title{
Cyberbullying the Meek: Conceptualization of University Undergraduate Students
}

\author{
Bismillah Sahar ${ }^{1}$ Dr. Ejaz Ahmad Mirza ${ }^{2}$ Shakeela Parveen ${ }^{3}$
}

1. Ph D Scholar, IER, University of the Punjab, Lahore, Punjab, Pakistan

2. Ph D Scholar, Education Officer, QAED Punjab, Pakistan

1. Ph D Scholar, IER University of the Punjab, Lahore, Punjab, Pakistan

\begin{tabular}{|c|c|}
\hline D & \\
\hline $\begin{array}{l}01,2019 \\
: 5,2019 \\
1,2019\end{array}$ & $\begin{array}{l}\text { Cyberbullying happens through the data information } \\
\text { technology through cell phones, instant messages, email, social } \\
\text { networks, pictures, web journals, chat room, videos are a few } \\
\text { cases of Cyberbullying. Cyberbullying is one of the darker and } \\
\text { all the more upsetting perspectives to the developing openness }\end{array}$ \\
\hline $\begin{array}{l}\text { zation } \\
\text { ng, }\end{array}$ & $\begin{array}{l}\text { students easily become the victim of Cyberbullying. This } \\
\text { dissertation examined the conceptualization of university } \\
\text { undergraduate students about Cyberbullying the meek. The }\end{array}$ \\
\hline ponding & $\begin{array}{l}\text { study was qualitative in nature and mix method research design } \\
\text { was used to conduct this study. The data collection instruments } \\
\text { were semi-structured interview and questionnaires. The } \\
\text { responses of } 20 \text { students collected through focus group } \\
\text { interview and responses of } 100 \text { students collected with } \\
\text { questionnaire. The present study revealed that meek students } \\
\text { commonly became the victim of Cyberbullying. Majority of } \\
\text { students said that Cyberbullying is affecting their academic } \\
\text { performance. In present study students recommend that } \\
\text { institutions should make policy to prevent Cyberbullying. }\end{array}$ \\
\hline
\end{tabular}

\section{Introduction}

The use of information and communication technologies such as e-mail, cell phone, pager, text messages, instant messaging, personal web sites or blogs and online personal polling web sites used to promote deliberate, repeated and hurtful behavior by an individual or group, with the intent to harm others is called Cyberbullying (Smith et al., 2008). This new format of communication has initiated new areas of concern and thus new avenues for research and study. Past studies of Cyberbullying have primarily focused on the adolescent years with emphasis on technologies used, reactions to cyber-harassment and the extent of the experience. This exploratory study designed to investigate Cyberbullying the meek: conceptualization of university under graduate students. In the late 1970"s Dan 
Olweus led social and psychological bullying research and provided a generalized understanding of two primary forms direct and relational, or indirect, bullying. Much of this research focused on students who were either bullies or victims.

Chapellet al. (2006) evaluated undergraduate students to determine the continuance of being a bully, victim, or bully-victim from elementary school through university. Interestingly, over seventy percent of students who were bullied in high school and elementary school bullied others in university. Forty to over fifty of students who had been bully-victims or bullies (respectively) in elementary and high school repeated the pattern in university.

Ybarra and Mitchell (2004) reported an increase of psychosocial problems in those reporting cyberbullies/victim behaviors including: problem behaviors, drinking alcohol, smoking, and depression and low commitment to academics. Somewhat alarming are the incidences of school shootings where the perpetrators report suffering from bullying behavior. In addition, university counseling centers report increasing concerns of anxiety, depression and suicidal ideation with the undergraduate university student (Chapell et al, 2006). Research regarding incidents of bullying on campus is imperative to providing a pro-active approach to the education of the 21st century student. The advent of affordable, user-friendly technology has brought bullying into cyberspace.

Olweus (1993) states that those students who are seen as meek are well on the way to be bullied, and hence welcome comparisons with the depiction of passive students in the school bullying literature, they likewise propose that as opposed to just comprehension tameness (or passivity) as an individual character trail, it is vital to consider the capacity it performs in harassing collaborations. Someone may be bullied on the grounds that they are seen to be compliant and along these lines, a simple target.

In any case, in the meantime, being easygoing and agreeing to preposterous requests by companions could be seen by the individual being bullied as a key method for abstaining from being subjected to all the more straightforwardly physical negative activities. Consequently, in the social and cultural connection of the school, it is insufficient to comprehend meekness (or lack of involvement) as just an individual character quality. Maybe, it is important to recognize the social capacity it performs in bullying situation regarding facilitating bullying but also in negotiating its outcomes (Horton et al., 2015).

\section{Material and Methods}

\section{Research Design}

Keeping in view the purpose of the study, mixed-method approach which enables in-depth and descriptive analysis of selected sample was adopted as research method. 


\section{Population and Sampling}

The population of the present study was comprised of the students of two undergraduate programs. Total numbers of B.S.Ed. Honors students were 55 and B.Ed. Honors students were 36 of Institute of Education and Research, University of the Punjab, Lahore. Purposive sampling technique was used to select the sample. The sample was comprised of all students of both under graduate programs. Twenty students (ten from each program) for interview and hundred students (fifty form each program) for questionnaires and were selected from both programs.

\section{Instrumentation}

After an extensive literature review the instrument of the study was developed by the researcher. Instruments of the study were questionnaires and semi-structured interview. Questionnaire was comprised of twenty-three items; the response format was at ordinal scale and semi-structured interview was developed under five emerging themes. Reliability of the instrument was determined as 0.830 . To check the validity of the results of focus group interview triangulation and peer debriefing techniques used by the researcher.

\section{Analysis and interpretation of data}

Regarding the qualitative design, the researcher collected data from B.S.Ed. and B.Ed. honors 1stsemester of Institute of Education and Research, University of the Punjab, Lahore, Pakistan. The researcher collected the data from 100 students of Institute of Education and Research, University of the Punjab through questionnaire consisting of 23 Items and focus group interview. For data analysis non parametric technique Mann-Whitney U Test was used. The Mann-Whitney U Test compares medians. The results of data analysis were presented in the form of tables. For understanding and explanation of the results interpretation was presented after the tables.

The analysis of focus group interview was done under two stages. In the first stage, code was generated from the obtained data. In the second stage codes were merged to generate themes and these were interpreted keeping in the research objectives and research questions of the study. The results were presented and discussed under themes namely understanding of students about Cyberbullying, the reasons of students involvement in Cyberbullying, meek students normally become the victim of Cyberbullying, preventive measures can be adopted by institutions for Cyberbullying and Cyberbullying affect students' academic achievement.

\section{Responses of B.Ed. Honors students}

The results were presented and discussed under five themes. The researcher was analyzed the data gathered through focus group interview from 10 students of 
B.S.Ed. Honors program of Institute of Education and Research, University of the Punjab. All participants took part in given the answer of all questions.

\section{Question 1}

\section{Understanding of students' about Cyberbullying}

Eight out of ten interviewees mentioned that they have already understanding about Cyberbullying and two interviewees mentioned that they did not about Cyberbullying before this interview. Ten out of ten interviewees used electronically devices and social communication pages.

\section{Question 2}

\section{Reasons of students' involvement in Cyberbullying}

All the interviewees agreed that most of the students were involved in Cyberbullying. Three out of ten interviewees mentioned that students involved in Cyberbullying for revenge. One interviewee asserted that bully want to torture others mentally or emotionally and get satisfaction from their act of irritating others. One out of ten interviewees claimed that the students involved in bullying because of their nature. One participant claimed that she faced bullying by her class fellows directly on Facebook and WhatsApp. One participant asserted that most of the students used social pages for bullying as it is easy to threat other online rather face to face. One interviewee said that lack of training of parents ${ }^{\text {ee }}$ major cause of involvement in Cyberbullying. One interviewee claimed that possessive students mostly involve in Cyberbullying. Three out of ten students agreed that bully'shome environment is the basic factor of their involvement in such kind of activities. Three out of ten students believed that students sometime involved in bullying due to jealousy with the victim. One participant claimed that lack of co-curricular and extracurricular activities caused of increase in Cyberbullying, less social activities is also big reason. One interviewee asserted that easy access to electronically devices played major role in promoting Cyberbullying.

\section{Question 3}

\section{Meek students normally become the victim of Cyberbullying}

At the responded of this question eight out of ten students mentioned that meek students mostly became the victim of Cyberbullying because bullies knew that meek students will not try to leak the information. Three interviewees"e said that yes, shy students mostly became the victim of Cyberbullying because they unable to give counter attack. Two participants believed that sometime over confident studentse became the victim of bully because they think that no one can bully them. Two participants asserted that both shy \& confident students became the victim of Cyberbullying equally. Two students claimed that shy students became victim because bullies think that shy individuals cannot give them reaction and they tolerate it silently. 


\section{Question 4}

\section{Preventive measures can be adopted by institutions for Cyberbullying}

Ten out of ten students mentioned that there must be a system to stop such kind of activities. Ten out of ten interviewees emphasized that there should be complaint office/ box in the institutions so the institutions could take steps against bullies. Four out of ten students mentioned that teachers should guide students during lectures and seminars that how to use technology positively and how to tackle with negative use of it. Two out of ten interviewees mentioned that students who involved in such king of activities must be struck out from the university so that other students would not try to involve in Cyberbullying ever. Three out of ten interviewees mentioned that university should arrange lectures, seminars"e and campaigns" to disseminate information regarding Cyberbullying and aware students how to deal with such type of students who involved in Cyberbullying. Two out ten students stressed that parents should involve stopping Cyberbullying and should careful about giving children electronic devices.

\section{Question 5}

\section{Cyberbullying affect students' academic achievement}

Ten out of ten interviewees mentioned that Yes; Cyberbullying affect the academic achievement of the students. One out of ten interviewees stated students became habitual using mobile all the time so this habit affects a lot on their studies. All participants claimed that Cyberbullying detract mentally and emotionally both the bully and the victim equally.

\section{Responses of B.S.Ed. Honors students}

The results were presented and discussed under themes. The researcher was analyzed the data gathered from focus group interview from 10 students of B.Ed. Honors program of Institute of Education and Research, University of the Punjab. All participants took part in given the answer of all questions.

\section{Question 1}

\section{Understanding of students' about cyberbullying}

Ten out of ten interviewees mentioned that they have already heeded the term Cyberbullying before and one interviewee mentioned that "It Starts from Leakage of Phone Number". Question 2Reasons of students' involvement in Cyberbullying All the interviewees agreed that students involved in Cyberbullying. Seven out of ten interviewees asserted that the reason of students involvement in Cyberbullying is mostly due to their bad company and lack of proper training by their parents/ guardians. Two of the students remarked that students take 
Cyberbullying as an enjoyment, while one of the female students reported that "students involved in it as they are not able to understand the difference between right and wrong". One participant believed that students create fake accounts on different communication pages for bullying others. One interviewee stated that students involve in bullying because they want to impose their view on others. One participant believed that most of the time close friends involved in bullying to each other. Two interviewees remarked that they encountered bullying when they shared some secret with some friends. One participant said that even friends on Facebook involved in try to save pictures from her wall which is very irritating. One participant asserted that in her class, five to six students involved in bullying others. One participant believed that bully's intentions were that they want other to obey them.

\section{Question 3}

\section{Meek students normally become the victim of Cyberbullying}

At the response of this question eight out of ten students mentioned that meek students mostly became the victim of Cyberbullying because the bullies knew that meek students will not try to leak their activity. One out of ten student mentioned that it is not necessarily that only meek became the victim of Cyberbullying he/she mentioned that "No Body Safe from the Bullies". One out of ten interviewee mentioned that over confident students could also became the victim of Cyberbullying due to their over confident and he/she mentioned that meek students were also involved in bullying sometime because he/she thought that nobody can predict that he/she involved in such type of activity. One interviewee believed that only those students became victimized who feel irritating with it.

\section{Question 4}

\section{Preventive measures can be adopted by institutions for cyberbullying}

Ten out of ten students mentioned that there must be a system to stop such kind of activities. Four out of ten students mentioned that teachers should guide students during lectures that how to use technology positively. Two out of ten interviewees mentioned that students who involved such king of activities must be struck out from the university so that other students would not try to involve in cyberbullying. Three out of ten interviewees mentioned that university should arrange lectures, seminars ${ }^{\text {ee }}$ and campaignse to disseminate information regarding cyberbullying and aware students how to deal such type of students who involved in cyberbullying. One out ten students mentioned that parents should involve stopping cyberbullying. One interviewee said that only useful pages should be liked.

\section{Question 5}

\section{Cyberbullying affect students' academic achievement}


Ten out of ten interviewees mentioned that Yes; Cyberbullying affect the academic achievement of the students. On out of ten interviews mentioned sometimes students are irritated at that level they thought to leave the institute. Four interviewees asserted that victims' academic achievement affected the most and negativity behavior increased. Three participants believed that both persons the bully and the victims' academic achievement affected. One interviewee said that bullies became habitual with their activities so their academic achievement could not affect.

Table 1

Difference b/w B.S.Ed. Honors and B.Ed. Honors male and female students' opinion

\begin{tabular}{ccccccc}
\hline Programs & Gender & $\mathrm{N}$ & Median & Mann-Whitney & Z-Value & Sig-2 Tailed \\
\hline B.S.Ed. & Male & 2 & 32.50 & 42.50 & -0.274 & 0.784 \\
\hline & Female & 48 & 33.00 & & & \\
\hline B.Ed. & & 4 & 40.10 & 37.00 & -1.97 & 0.49 \\
\hline & & 46 & 39.00 & & & \\
\hline
\end{tabular}

Responses of B.S.Ed. Honors students revealed that there is no significance difference between the opinion of male and female students of B.S.Ed. Honors program, Institute of Education and Research, University of the Punjab. Responses of B.Ed. Honors students revealed that there is significance difference between the opinion of male and female students of B.Ed. Honors program, Institute of Education and Research.

Table 2

Cyberbullying the meek (BS. Ed Honors and B.Ed. Honors)

\begin{tabular}{ccccc}
\hline Programs & Question & N & Mean & SD \\
\hline $\begin{array}{c}\text { B.S.Ed. } \\
\begin{array}{c}\text { Only shy students become the victim of cyber } \\
\text { bullying }\end{array}\end{array}$ 50 & 1.70 & .863 \\
B.Ed. & $\begin{array}{c}\text { Only shy students become the victim of } \\
\text { Cyberbullying }\end{array}$ & 50 & 1.86 & .808 \\
\hline
\end{tabular}

Responses of both program students revealed that meek students mostly become the victim of Cyberbullying.

Discussion

In the response of "understanding of students about cyberbullying" eighteen out of twenty interviewees claimed that they have already understanding about cyberbullying and two of them mentioned that the term cyberbullying was new for them before this interview. Smith and Steffgen, (2013) in their research supported the above research findings and said that the ways youngsters impart through Information Communication Technology (ICT) are quickly changing; in the course of 
the last few years the spread of smart phones has empowered somebody to utilize his/her cellular telephone both for web and also text messaging and calling.

All interviewees agreed that most of the students were "involved in cyberbullying". Smith and Steffgen, (2013) said that a manifestations of cyberbullying incorporate posting onsite pages including social networking sites (e.g. Twitter, Facebook, My space, WeChat). New illustrative words are coming in: For instance, "Sexting" depict the flow of sexualized pictures on cellular telephones or the web; "Trolling" portrays tireless oppressive remarks on a specific site; "Griefing" depicts provocation of somebody in a cyber-game or virtual world. At the response of "meek students mostly become the victim of cyberbullying" sixteen out of twenty students agreed with that statement. Olweus (1993) supported the above finding that some children are bullied precisely because they are perceived to be passive and hence easy victims. For example, stated that the behavior and attitude of the passive victims signal to others that they are insecure and worthless individuals who will not retaliate if they are attacked or insulted"e. Twenty out of twenty students asserted that there must be some preventive "measures adopted by institutions to stop cyberbullying". Faryadi, (2011) stayed the above finding that there is a critical need to comprehend the issues confronted by the victims of those tangible and proactive measures can be taken by institutional authorities, teachers and parents to address this worldwide issue.

All twenty interviewees emphasized on that "Yes Cyberbullying affects the academic achievement of the students". Juliana, (2010) supported the above research finding that the cyber victims, under incredible emotional disturbance, are not able to focus on their studies, and therefore their academic achievement is unfavorably influenced. Bulent, (2009) said that the psychological impacts of cyberbullying in our society and institutions can't be ignored any more. For quantitative data analysis Mann-Whitney U Test was used. The Mann-Whitney U Test actually compares medians. The research findings revealed that there is no significance difference between the opinion of male and female students of B.S.Ed. Honors program, responses revealed that there is significance difference between the opinion of male and female students of B.Ed. Honors.

\section{Conclusion and Recommendation}

The present study revealed that a large majority of students had understanding about the cyberbullying. The present study revealed that all students accepted that students involved in cyberbullying by using social websites such as (Facebook, WhatsApp and WeChat. The present study revealed majority of the students proclaimed that meek students mostly became the victim of cyberbullying. The findings of the study concluded that majority of students said that cyberbullying was effecting their performance. Social websites should launch the system where the undesired material could filter before reached the user page. Institutes should conduct lectures and seminars for the awareness of parents about cyberbullying. So they can play their role to prevent their children from the negative effect of cyberbullying. 


\section{References}

Bulent, D. (2009). Psychological Needs as a Predictor of Cyberbullying: A Preliminary Report on College Students,Educational Sciences: Theory and Practice, 1307-1325.

Chapell, M.S., Hasselman, S.L., \&Kitchin, T. (2006). „Bullying in elementary school, highschool and college ${ }^{e c}$. Adolescence, 41, 633-648.

Faryadi, Q. (2011) Cyberbullying and academic achievement [pdffile].International Journal of Computational Engineering Research, 1:24.

Juliana, R. (2010). Text-Bullying: Associations with Traditional Bullying and Depression among New Zealand Adolescents. Journal of School Violence, 74-97.

Horton, P.,Lindholm, K. S., \&Nguyen. H. T. (2015) Bullying the meek: a conceptualization of Vietnamese school bullying, Research Papers in Education, 30:5, 635-645. DOI:10.1080/02671522.2015.1027728

Olweus, D. (1993). Bullying at school: What we know and what we can do. Cambridge, MA: Blackwell.

Smith, p.k., \&Steffgen G., (2013). Cyberbullying through the new media: Findings from an internationalwork. NewYork:Psychological press.

Smith, P.K., Mahdavi, J., Carvalho, M., et al (2008). Cyberbullying: its nature and impact insecondary school pupils. Journal of Child Psychology and Psychiatry, 49, 376-385.

Ybarra, M. L and Mitchell, K.J. (2004). „Online aggressor/targets, aggressors, and targets: acomparison of associated youth characteristics ${ }^{e e}$. Journal of Child Psychology and Psychiatry,45, 1308-1316. 